\title{
Evaluation of Several Biochar Types as Inoculant Carrier for Indigenous Phosphate Solubilizing Microoorganism from Acid Sulphate Soil
}

\author{
Nurul Husna ${ }^{1 *}$, Dedik Budianta ${ }^{2}$, Munandar ${ }^{3}$, Adipati Napoleon ${ }^{2}$ \\ 1 Faculty of Agriculture, IBA University, J. Mayor Ruslan, Palembang 30114, South Sumatra, Indonesia \\ 2 Department of Soil Science, Faculty of Agriculture, University Sriwijaya, Inderalaya 30662, South Sumatra, \\ Indonesia \\ 3 Department of Agronomy, Faculty of Agriculture, University Sriwijaya, Inderalaya 30662, South Sumatra, \\ Indonesia \\ * Corresponding author's e-mail: nurulight2001@gmail.com
}

\begin{abstract}
The research aimed at evaluating four biochar types which have the most adequate characteristics as inoculant carrier of indigenous Phosphate Solubilizing Microorganism (PSM) from acid sulphate soil. The observed biochar characteristics consist of the bulk density, total pore space, water holding capacity, C organic, $\mathrm{N}, \mathrm{pH}$, EC, charcoal percentage, and ash content. The pore diameters and photomicrograph of biochar were observed by using SEM. The viability test was conducted in order to determine the appropriateness of biochar as PSM inoculant through inoculation on four biochar types made of rice husk, coconut shell, corncob, and oil palm empty bunch, followed by six months storage period. Monthly observation was conducted related to the PSM population, $\mathrm{pH}$, and moisture content. The results show that interaction of biochar types and storage periods has no significant effect on the PSM viability, $\mathrm{pH}$, and moisture content. The PSM viability of four biochars after six months storage period is

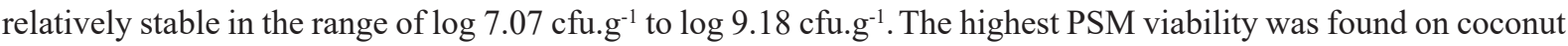
shell biochar with the magnitude of $\log 9.18{\mathrm{cfu} . \mathrm{g}^{-1}}$ and $\mathrm{pH}$ of 7.01 as well as moisture content of $26.86 \%$ after six months storage period. This research offers the advantage of using agricultural waste substance as biochar that capable to maintain microbial viability with six months storage period.
\end{abstract}

Keywords: biochar, inoculant carrier, phosphate solubilizing microorganism, viability.

\section{INTRODUCTION}

The efforts to overcome soil fertility constraint at acid sulphate soil are made by adding soil conditioner such as biochar (Nurita and Saleh, 2016 ; Annisa and Nursyamsi, 2016) and phosphate solubilizing microorganisms. Biochar is a product from biomass combustion under the conditions of the lack or low oxygen (Xu et al., 2012; Sohi et al., 2013). Biochar application is able to improve several physical and chemical characteristics of soil, such as increasing soil aggregation and water holding capacity, decreasing soil strength, as well as increasing $\mathrm{C}$ organic of soil, soil $\mathrm{pH}$ and Cation Exchange Capacity (Masulili et al., 2010;
Major et al., 2012; Rees et al., 2014). The porous structure of biochar can increase the soil surface area, which in turn is capable of retaining water and nutrients such as nitogen and phosphorus, a condition which supports the growth of bacteria and development of fungus hyphae (Graber et al., 2010; Lehmann et al., 2011; Jafaar et al., 2014).

However, the studies focusing on biochar utilization as potential microbial carrier are still limited. The role of microbial carrier is to keep microbes in stable condition and high numbers before they can be used on soil. Proper carrier substance is important in order to prevent the death of microbes due to starving, being eaten by predators, accelerated death of microbial cells as 
well as low activity. In order to be used as proper inoculant carrier agent, the biochar should have proper characteristics. The availability of raw material is abundant, easily found at the location with low price, it has high water holding capacity, good aeration property, and is capable of supporting the growth of bacteria or fungi. The inoculant should not be toxic, environmental friendly and easily produced. The carrier substance should be sterile and easily managed in the field such as easy to be mixed into soil or plant as well as easily packed (Thies and Rillig, 2009; Hale et al., 2015).

Currently, the generally used inoculant carrier substances are peat, vermiculite, alginate and others, which are relatively expensive and available in limited quantity. The raw material of biochar, such as rice husk, corncob, coconut shell and oil palm empty bunch are local resources which are not used optimally. Biochar is economically more feasible to be used as carrier substance compared to other substances, because it is available in abundant quantities, cheap, easy to obtain, and readily-available.

The biochar characteristics such as high internal porosity, high specific surface area and ability to absorb compounds and bacteria showed that this substance is relatively conducive to be used as inoculant carrier (Downie et al., 2009; Atkinson et al., 2010; Sohi et al., 2010). The biochar is a good substrate for microorganisms because it has high carbon content, good nutrients value, and has no toxic substance. The biochar preparation done through pyrolysis process makes biochar relatively sterile and suitable as microbial carrier (Hale et al., 2015; Egamberdieva et al., 2017).

The previous studies showed that biochar had ideal pore size for the growth of soil microorganisms (Verheijen et al., 2009; Vanek et al., 2016). According to Vanek et al. (2016), the biochar pore with internal diameter of 0.3 to $30 \mu \mathrm{m}$ had important role to microbial population that can be collected within biochar. This advantage provides an opportunity for biochar to be used as conditioner of acid sulphate soil and also as PSM carrier, which is highly needed on acid sulphate land. The PSM which is used as inoculant in this study was obtained from selection result for acid sulphate land that is tolerant to $\mathrm{AlPO}_{4}$ and $\mathrm{FePO}_{4}$ at the concentration of $1500 \mathrm{mgL}^{-1}$ and $\mathrm{pH}$ value of 3 .

The research aimed at identifying the characteristics of several biochar types that are most suitable as indigenous PSM inoculant carrier for acid sulphate land. The indication of suitability is that the microba vialibility should be kept high and stable during storage period. It is hoped that the result from this study can be used to identify the biochar development potential as PSM carrier, especially for acid sulphate land.

\section{MATERIAL AND METHODS}

This research was conducted at Palembang, South Sumatra from November 2017 to May 2018 in the Laboratory of IBA University Palembang and Microbiological Laboratory, Biological Department, Faculty of Mathematics and Natural Science, Sriwijaya University, Indralaya.

\section{Biochar production}

Four substances for biochar consisting of rice husk, coconut shell, oil palm empty bunch and corncob were air dried until moisture content level of $\pm 15 \%$. These substances were chopped to the size of $\pm 2 \mathrm{~cm}$ and $5 \mathrm{~kg}$ of these substances were subsequently put into the pyrolysis tube. The pyrolysis process was for 8 hours at temperature of $500-600{ }^{\circ} \mathrm{C}$. The biochar which was cooled for \pm 24 hours was ground and then sieved using 80 mesh sieve.

\section{Physical and chemical characteristics of biochar}

The physical and chemical characteristic of biochar consist of carbon (Walkley and Black), nitrogen (Kjehdahl), $\mathrm{pH}\left(\mathrm{H}_{2} \mathrm{O}\right)$, electrical conductivity, percentage of water holding capacity (WHC), bulk density, total pore space, photomicrograph by using a scanning electron microscope (SEM), pore size or diameter, carbon percentage, and ash content.

\section{Inoculant preparation and inoculation process of biochar}

Three types of bacterial isolates, consisting of Paenibacillus alvei, Burkholderia cepacia and Acinetobacter baumannii were cultured within nutrient broth for 72 hours at the temperature of $30^{\circ} \mathrm{C}$ and put in the shaker machine at the velocity of $100 \mathrm{rpm}$, whereas the fungi isolate of Penicillium variabile was cultured within PDA (Potato Dextrose Agar) medium for 72 hours. The PSM was mixed and incubated for 24 hours before its application. The PSM 
population density within medium is $5.31 \times 10^{12}$ cfu $\mathrm{mL}^{-1}$. Four biochar types consisting of rice husk, coconut shell, oil palm empty bunch and corncob were ground and then sieved until their size was $\pm 1 \mathrm{~mm}$; subsequently, they were sterilized within autoclave at temperature of $121^{\circ} \mathrm{C}$ for 15 minutes. The inoculation process was conducted by spraying $1.2 \mathrm{ml}$ microba culture and $11 \mathrm{ml}$ destilate water into biochar using syringe in order to produce $40 \%$ relative humidity and subsequently $30 \mathrm{~g}$ of biochar was put into poly prophylene plastic pouch, followed by incubation at room temperature.

\section{Microbial viability test in biochar}

Thirty grams of biochar in plastic pouch was arranged by using factorial completely randomized design with three replications. The first factor was biochar types $(\mathrm{B} 1=$ rice husk biochar, $\mathrm{B} 2$ $=$ coconut shell biochar, $\mathrm{B} 3=$ corncob biochar and B4 = biochar of oil palm empty bunch). The second factor was incubation times (T0 $=0$ month, $\mathrm{T} 1$ $=1$ month, $\mathrm{T} 2=2$ months, $\mathrm{T} 3=3$ months, $\mathrm{T} 4=$ 6 months). The observed parameters consisted of:

- Bacterial population was observed at 0 month, 1 month, 2 months, 3 months and 6 months incubation period by using the plating method.

- The $\mathrm{pH}$ was observed at 0 month, 1 month, 2 months, 3 months and 6 months period.

- Moisture content was observed at 0 month, 1 month, 2 months, 3 months and 6 months period.

\section{Data analysis}

The bacterial viability test was conducted by using Anova test and further tested by using least significant difference (LSD) of 5\%.

\section{RESULTS AND DISCUSSION}

\section{Physical and chemical characteristics of biochar}

The biochars from oil palm empty bunch (OPEB), corncob (CC) and rice husk (RH) have relatively similar bulk densities with magnitude of $0.61,0.66$ and 0.64 , whereas coconut shell biochar (CS) has the highest bulk density with magnitude of 0.92. Because the coconut shell biochar has the highest bulk density, it has lower total pore space $(65 \%)$ and water holding capacity (120.66\%) than OPEB, CC and RH biochars. The chemical composition from four biochars is different depending on raw material types. The biochar of CS in general had higher nutrients concentration, as indicated by the highest $\mathrm{EC}$ value. C-organic content of CS, CC, RH and OPEB biochars was higher than 50\% with magnitude of $64.12 \%, 65.26 \%, 59.84 \%$ and $51.24 \%$, respectively, as well as high $\mathrm{C} / \mathrm{N}$ ratio. The $\mathrm{pH}$ value of OPEB, CS and RH biochars is relatively similar with the magnitude of 6.26, 7.74 and 7.01 , respectively. On the other hand, the high $\mathrm{pH}$ is found on CC biochar with magnitude of 9.95. The highest ash content and the lowest charcoal percentage are found on $\mathrm{CC}$ biochar with the magnitudes of $40.21 \%$ and $30 \%$, respectively (Table 1 ).

\section{Microbial viability during storage period}

The analysis of variance and further test results shows that the biochar types (inoculant carrier substance) and storage as well as their interaction had no significant effect $(p>0.05)$ on the viability of PSM inoculant. Four biochar types in this study are capable of supporting inoculant life sustainability with average value of more than $\left(\geq 10^{7} \mathrm{cfu} \cdot \mathrm{g}^{-1)}\right.$, which is considered as feasible population density as microbial carrier agent.

Table 1. Physical and chemical characteristics of biochars

\begin{tabular}{|c|c|c|c|c|}
\hline \multirow{2}{*}{$\begin{array}{c}\text { Physical and chemical } \\
\text { characteristics }\end{array}$} & \multicolumn{4}{|c|}{ Type of Biochar } \\
\hline & Oil palm empty bunch & Coconut shell & Corncob & Rice husk \\
\hline Bulk density $\left(\mathrm{g} \cdot \mathrm{cm}^{-3}\right)$ & 0.61 & 0.92 & 0.66 & 0.64 \\
\hline Total pore space (\%) & 77.00 & 65.00 & 74.66 & 76.00 \\
\hline WHC (\%) & 162.66 & 120.66 & 168.00 & 156.66 \\
\hline C organic $(\%)$ & 51.24 & 64.12 & 65.26 & 59.84 \\
\hline $\mathrm{N}$ total $(\%)$ & 0.13 & 0.36 & 0.59 & 0.64 \\
\hline $\mathrm{pH} \mathrm{H}_{2} \mathrm{O}$ & 7.01 & 7.74 & 9.95 & 6.26 \\
\hline $\mathrm{EC}\left(\mathrm{dS} \mathrm{m}^{-1}\right)$ & 0.95 & 1.15 & 0.74 & 0.35 \\
\hline Ash content (\%) & 30.98 & 36.33 & 40.21 & 29.58 \\
\hline Charcoal percentage (\%) & 33.75 & 36.43 & 30 & 45 \\
\hline
\end{tabular}


The test results show that all biochar substances are useful as PSM inoculum carrier, but they had different efficacies. It is based on the differences of chemical and physical characteristics from each biochar. The coconut shell biochar was identified as the best biochar to be used as inoculum carrier, compared to other biochars, because it has the capability of producing the highest cell density after six month storage period. The PSM population within the carrier substance of coconut shell biochar was continuously higher than that of RH, CC and OPEB biochars. All tested biochars had no detrimental effect on the inoculant population. The inoculant population decreases during the first month storage and then slightly increases in the second month for $\mathrm{RH}$ and OPEB biochars. The population of PSM tends to continuously decrease up to six month storage period. The CS biochar has the highest final population with magnitude of $\log 9.18 \mathrm{cfu}^{-1} \mathrm{~g}^{-1}$, followed by RH biochar of $\log 8.14 \mathrm{cfu}^{-\mathrm{g}^{-1}}$, CC biochar of 7.12 cfu. $\mathrm{g}^{-1}$ and OPEB biochar of $\log 7.07 \mathrm{cfu} . \mathrm{g}^{-1}$, respectively (Figure 1).

\section{$\mathrm{pH}$}

High cell density on coconut shell biochar is also related to its chemical characteristics, such as $\mathrm{pH}$ and $\mathrm{EC}$. The $\mathrm{pH}$ of biochar during storage period tends to decrease because PSM is still conducting metabolism activity. The decrease of $\mathrm{pH}$ occurred on all biochar types because the nutrient content and water content available within each carrier substance decrease in accordance to the storage times, whereas microbes which are capable of adapting will use $\mathrm{P}$ and produce organic acids resulting in a decrease of $\mathrm{pH}$ (Marra et al, 2012).
Table 2 shows that $\mathrm{pH}$ value of coconut shell biochar was still 7.01 up to six months storage period. The $\mathrm{pH}$ affects the PSM viability within its carrier medium. The growth of the PSM inoculant is not only affected by environmental factors, but also has effect on the environment. The bacteria can change the $\mathrm{pH}$ of its growth medium which is called chemical change. One example of this chemical change is the phosphatase enzyme activity required by PSM to catalyze the reactions related to cells growth (Behera et al., 2014). If the $\mathrm{pH}$ within a medium or environment is not optimum, then it will interfere with the enzymes activity, which in turn also interferes with the growth of bacteria itself.

In this study, the PSM is a mixed culture from three bacteria and one phosphate solubilizing fungus, i.e. Paenibacillus alvei, Burkholderia cepacia, Acinetobacter baumannii and Penicillium variabile. These four PSM are tolerant microbes, up to $\mathrm{pH}$ of 3.0. The $\mathrm{pH}$ condition of carrier substance which is more alkaline such as found on corncob biochar (9.11) and biochar of oil palm empty bunch (8.02) will inhibit the growth of PSM. The optimum $\mathrm{pH}$ for phosphate solubilizing bacteria is in the range of 6.5 to 7.5 and $\mathrm{pH}$ for phosphate solubilizing fungi is in the range of 5.0 to 5.5 (Khan et al., 2014). According to Rousk et al. (2009), there is no increase of total biomass at $\mathrm{pH}>7$, even if the fungi growth will drastically decrease. The result of $\mathrm{pH}$ measurement shows that the $\mathrm{pH}$ condition in the carrier substance has highly significant effect on the viability of microbial cells. The coconut shell and rice husk biochars have the $\mathrm{pH}$ values within the optimum range; thus, they had higher cell density compared to corncob and oil palm empty bunch biochars. In addition to $\mathrm{pH}$, the nutrients content and water content provide

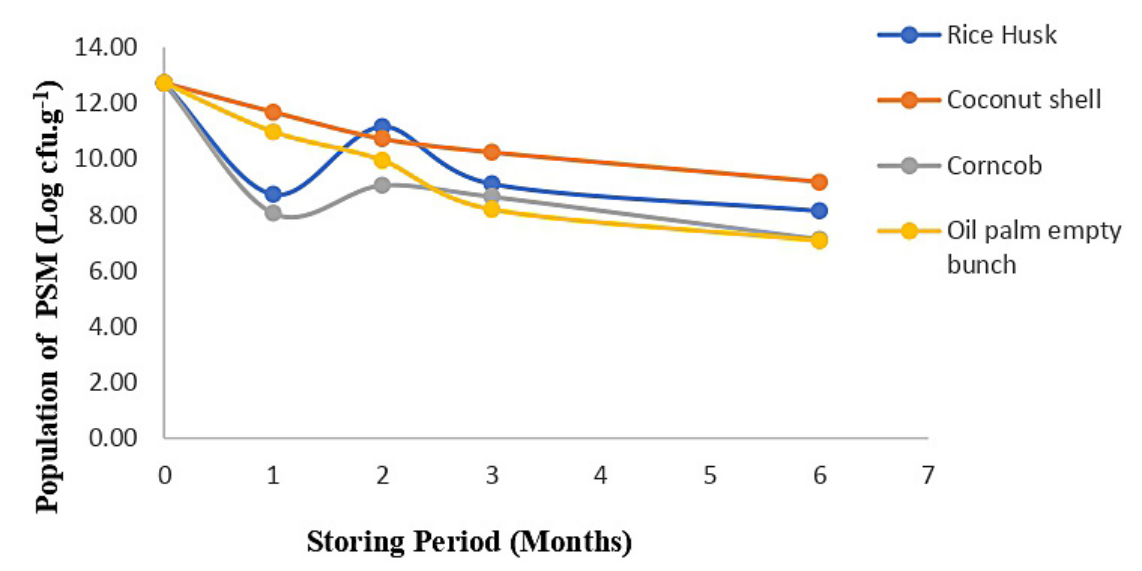

Figure 1. PSM population on several biochar types during storage period 
Table 2. $\mathrm{pH}$ for several biochar types during storage period

\begin{tabular}{|l|c|c|c|c|c|}
\hline \multirow{2}{*}{\multicolumn{1}{c|}{ Biochar types }} & \multicolumn{5}{c|}{$\mathrm{pH}$} \\
\cline { 2 - 6 } & 0 month & 1 month & 2 months & 3 months & 6 months \\
\hline Rice husk & 7.55 & 6.6 & 6.42 & 6.02 & 5.82 \\
\hline Coconut shell & 9.08 & 8.22 & 8.15 & 7.42 & 7.01 \\
\hline Corncob & 10.72 & 10.23 & 10.1 & 9.52 & 9.11 \\
\hline Oil palm empty bunch & 8.93 & 8.78 & 8.58 & 8.48 & 8.02 \\
\hline
\end{tabular}

Table 3. Moisture content of several biochar types during storage period

\begin{tabular}{|l|c|c|c|c|c|}
\hline \multirow{2}{*}{\multicolumn{1}{c|}{ Biochar types }} & \multicolumn{5}{c|}{ Moisture content (\%) } \\
\cline { 2 - 6 } & 0 month & 1 month & 2 months & 3 months & 6 months \\
\hline Rice husk & 30.36 & 29.42 & 28.08 & 23.04 & 20.32 \\
\hline Coconut shell & 31.44 & 31.26 & 28.81 & 27.26 & 26.86 \\
\hline Corncob & 41.99 & 40.98 & 37.59 & 36.92 & 32.54 \\
\hline Oil palm empty bunch & 36.14 & 33.23 & 32.92 & 31.81 & 29.61 \\
\hline
\end{tabular}

suitable environment for microbial reproduction or proliferation (Santi and Goenadi, 2010). The coconut shell biochar has higher nutrient content, which was indicated by the EC value of 1.15 dS.m ${ }^{-2}$. The nutrient content such as $\mathrm{P}, \mathrm{K}, \mathrm{Ca}, \mathrm{Na}$ and $\mathrm{Mg}$ within biochar is the energy source for microbes to increase their life sustainability and survival.

\section{Moisture content}

The raw material type and pyrolysis process determine the physical and chemical characteristics of biochar (Downie et al., 2009). The bulk density and porosity are the physical characteristics which affect water holding capacity for each biochar. The moisture content of biochars after six-month storage period has a tendency to continuously decrease. The $\mathrm{CC}$ biochar has the highest moisture content after six months storage period, with the magnitude of $32.58 \%$ compared to OPEB biochar (29.61\%), RH biochar (20.32\%), and CS biochar $(26.86 \%)$ (Table 3 ).

In general, the moisture content at level of $40 \%$ or more is the optimum level for microbial activity (Lehmann et al., 2011). At lower moisture content, the osmotic potential and matrix potential restrict water availability resulting in hampered microbial growth (Glodowska et al., 2017). This condition leads to the population decline, in accordance to the storage time period, although it has no significant effect statistically (Table 3 ).

Although the coconut shell biochar has lower porosity and lower water holding capacity compared to three other biochars, these variables are not the only factors that determine the inoculant population density within carrier substance. Another physical characteristic that affect the cell density within biochar is pore size. The pore sizes determine the entry of biochar into pores or adhere on the biochar surface (microbial attachment).

\section{Pore size and SEM result}

The pore size distribution varies among four biochar types (Table 4). The rice husk biochar and oil palm empty bunch biochar have relatively uniform pore size with the diameter of $6.11 \mu \mathrm{m}$ and $6.91 \mu \mathrm{m}$, respectively. The coconut shell biochar had a relatively high variation in terms of pore diameters with the average value of $3.39 \mu \mathrm{m}, 7.09$ $\mu \mathrm{m}$ and $9.30 \mu \mathrm{m}$. On the other hand, corncob biochar has higher pore diameters with the magnitude of $14.6 \mu \mathrm{m}$ and $21.95 \mu \mathrm{m}$.

The SEM photographs also show the variation of pore diameter of biochars (Figure 2). The four biochar types have macropores with the size of $>50 \mathrm{~nm}$. The rice husk biochar has the most uniform pore size. The characterization of morphological heterogeneity by using SEM on the pore structure and surface shows the differences among four biochar types. The biochar of CC (Figure. 2a) has higher pore diameters than that of OPEB and RH biochars (Figure.2b and $2 c$ ). The biochar of CS exhibits extensive variation in terms of pore sizes (Figure.2d and 2e). 
Table 4. Average diameter of pore for four biochar types $(n=5)$

\begin{tabular}{|l|c|c|c|c|c|}
\hline \multirow{2}{*}{\multicolumn{1}{c|}{ Biochar types }} & \multicolumn{4}{|c|}{ Average diameter of pore $(\mu \mathrm{m})$} & \multirow{2}{*}{ Average } \\
\cline { 2 - 6 } & $<5$ & $5-10$ & $11-15$ & $16-20$ & 6.11 \\
\hline Rice husk & - & 6.11 & - & - & 6.91 \\
\hline Oil palm empty bunch & - & 6.91 & - & - & 6.59 \\
\hline Coconut shell $^{*}$ & 3.39 & 7.09 & 9.30 & - & 18.27 \\
\hline Corncob & - & - & 14.6 & 21.95 & \\
\hline
\end{tabular}
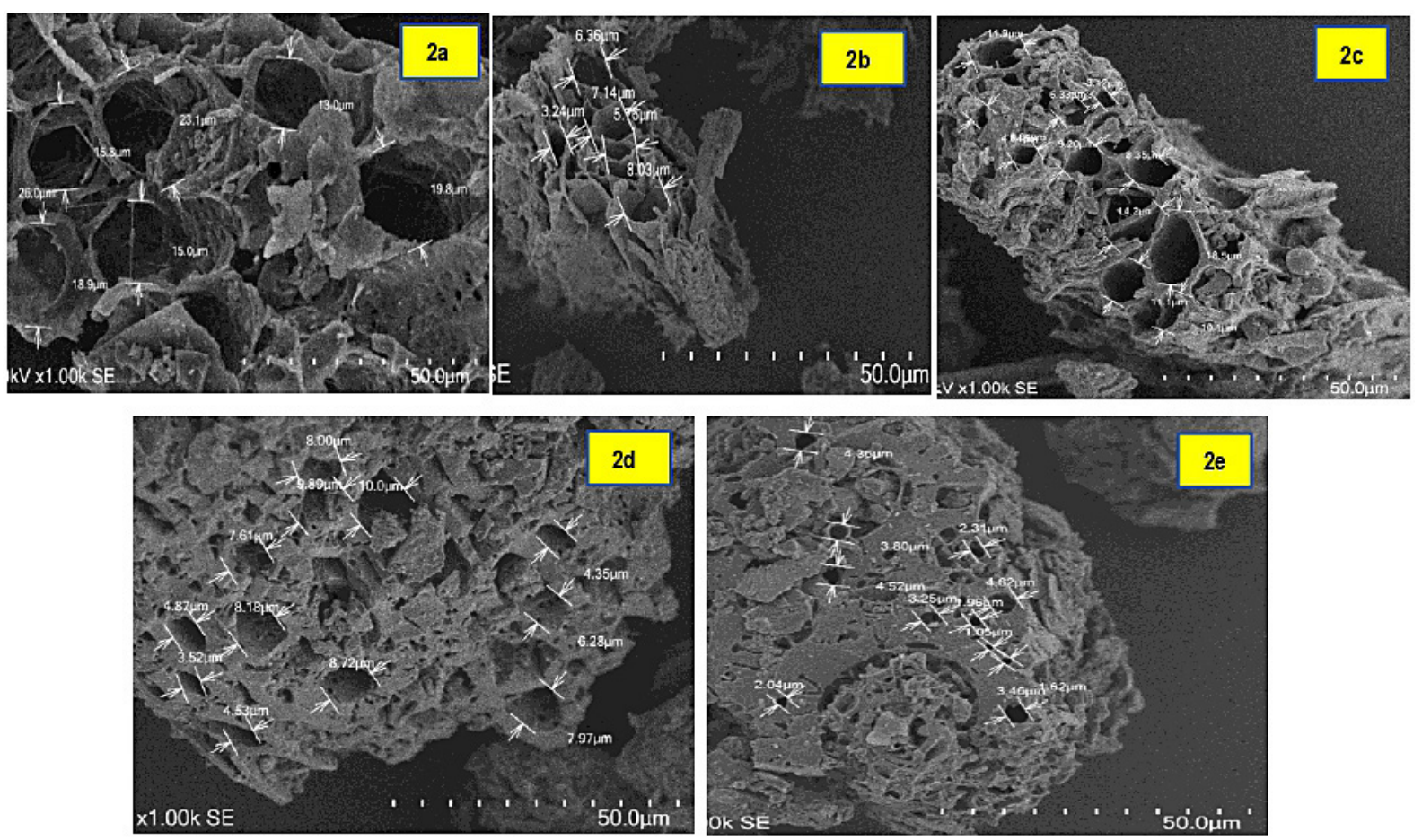

Figure 2. Pore diameter of biochars $(2 \mathrm{a}-$ corncob, $2 \mathrm{~b}$ - rice husk, $2 \mathrm{c}$ - oil palm empty bunch, $2 \mathrm{~d}$ and $2 \mathrm{e}$ - coconut shell)

The biochars having high pore size, such as OPEB, CC and RH (Figure $2 \mathrm{a}, 2 \mathrm{~b}$ and $2 \mathrm{c}$ ), show that the microbes are only located at surface of biochar or outside of pore space. On the other hand, the microbes for CS biochar are located within pore space and at surface of biochar. The pore size determines the adhesion between biochar and microbes. According to Vanek et al. (2016), the pore size for optimum adhesion should be 2 to 5 times higher than cells size if the microbes entering pores are about 2-4 $\mu \mathrm{m}$ for Acinetobacter sp. Adhesion can decrease at the pores having higher size or lower size either due to higher pore curvatures to increase adhesion or microbes will not entering into pores (Verheijen et al., 2009). Therefore, the biochar ability to retain microbes is highly varied, depending on the biochar characteristics such as ash content, pore size and volatile matter content.
The optimum pore size in this research was 2-4 $\mu \mathrm{m}$, which was found only on the coconut shell biochar (Table 4). The coconut shell biochar has variation in terms of pore size distribution, which enable microbes to adhere on the surface or pore space by using adhesion force, whereas rice husk, oil palm empty bunch and corncob biochars had greater pore size which rendered PSM to adhere on the surface or enter into pores (Figure 3a, $3 \mathrm{~b}, 3 \mathrm{c}, 3 \mathrm{~d}$ and $3 \mathrm{e})$.

Our results are in accordance with the study conducted by Saranya et al. (2011) who stated that the biochar from coconut shell substance was the best PSM carrier agent compared to such carrier substance as acacia wood biochar and lignite. The biochar is able to maintain the PSM population with the magnitude of $\log 10.79 \mathrm{cfu}^{-1} \mathrm{~g}^{-1}$ and moisture content of $25.22 \%$ after six-month storage period. The coconut shell biochar is able to maintain the PSM population with the magnitude 

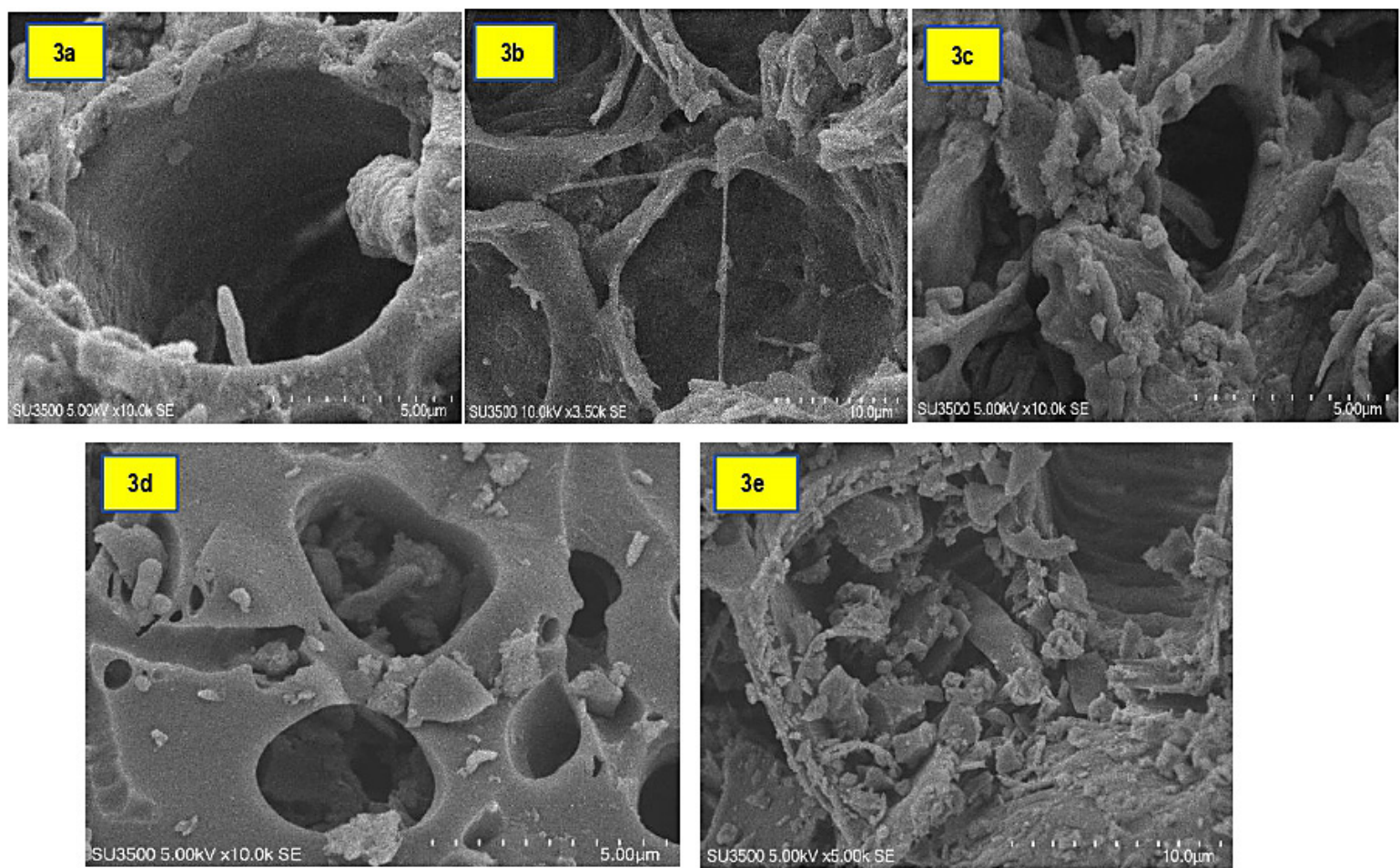

Figure 3. Biochars innoculated with phosphate solubilizing microbia with two months storage period $(3 \mathrm{a}$ - corncob, $3 \mathrm{~b}$ - rice husk, $3 \mathrm{c}$ - oil palm empty bunch, $3 \mathrm{~d}$ and $3 \mathrm{e}$ - coconut shell)

of $\log 9.18 \mathrm{cfu} . \mathrm{g}^{-1}$ and moisture content of $20.21 \%$ after six-month storage period. On the other hand, the biochars of rice husk, corncob and oil palm empty bunch that have final population with the magnitude of $\log 8.14 \mathrm{cfu}^{-\mathrm{g}^{-1}}, \log 7.12 \mathrm{cfu}^{-\mathrm{g}^{-1}}$ and $\log 7.07$ cfu. $^{-1}$ can also be used as inoculant carrier substances. These substance are capable of maintaining the PSM population with the magnitude of $>10^{7}$ cfu.g ${ }^{-1}$ after six months storage period with moisture content of $20.32 \%, 32.54 \%$ and $29.61 \%$, respectively.

\section{CONCLUSION}

On the basis of the results of this study, the biochars of rice husk, coconut shell, corncob and oil palm empty bunch have proper physical and chemical characteristics as carrier agents of phosphate solubilizing microbial inoculant. The use of these biochars was found to increase the survival of microbial inoculant up to six months, since it is free from toxic elements and readily-available. Moreover, biochar does not present any storage problem due to its limited moisture content. The coconut shell biochar is the most suitable carrier; it has the highest viability with the magnitude of $\log 9.18 \mathrm{cfu}^{-1} \mathrm{~g}^{-1}$ and $\mathrm{pH}$ of 7.01 as well as moisture content of $26.86 \%$ after six-month storage period.

\section{Acknowledgements}

The authors would like to thank Rector of Sriwijaya University through the Superior Research Profession Program for fiscal year 2017 that had already provided funding for research implementation.

\section{REFERENCES}

1. Annisa W. and Nursyamsi D. 2016. The effect of ameliorant, fertilizer and management system of acid sulphate soil on rice yield and methane emission. Journal of Land Resources, 2 (40), 51-64

2. Atkinson C.J., Fitzgerald J.D. and Hipps N.A. 2010. Potential mechanisms for achieving agricultural benefits from biochar application to temperate soils: a review. Plant Soil, (337), 1-18.

3. Behera, B. C., Singdevsachan, S. K., Mishra, R. R., Dutta, S. K. and Thatoi, H. N., 2014. Diversity, mechanism and biotechnology of phosphate solubilising microorganism in mangrove-A review. Biocatalysis and Agricultural Biotechnology, 3(2), 97-110. doi:10.1016/j.bcab.2013.09.008.

4. Downie A., Crisky A. and Munroe P. 2009. Physical properties of biochar. In: Biochar for Environmental Management. Lehmann, J. and Joseph, S. (Eds.), 2nd Ed. Earthscan Publications Ltd, London, pp 13-32 
5. Egamberdieva, Reckling M. and Wirth S. 2017. Biochar-based Brady rhizobium inoculum improves growth of lupin (Lupinus angustifolius L.) under drought stress. European Journal of Soil Biology, (78), 38-42.

6. Głodowska M., Schwinghamer T., Husk B., Smith D. 2017. Biochar based inoculants improve soybean growth and nodulation. Agric Sci, (8), 1048-1064

7. Graber E., Meller Harel Y., Kolton M., Cytryn E., Silber A., Rav David D., Tsechansky L., Borenshtein M. and Elad Y. 2010. Biochar impact on development and productivity of pepper and tomato grown in fertigated soilless media, (337), 481-496.

8. Hale L., Luth M. and Crowley D. 2015. Biochar characteristics relate to its utility as an alternative soil inoculum carrier to peat and vermiculite. Soil Biology and Biochem, (81), 228-235

9. Khan M.S., Zaidi A. and Ahmad E. 2014. Mechanism of Phosphate Solubilization and Physiological Functions of Phosphate-Solubilizing Microorganisms. In: Khan M., Zaidi A., Musarrat J. (eds) Phosphate Solubilizing Microorganisms. Springer, Cham.

10. Jaafar N.M., Clode P. L. and Abbott L.K. 2014. Microscopy observations of habiTable space in biochar for colonisation by fungal hyphae from soil. J Integr Agr, 13(3) : 483-490.

11. Lehmann J., Rilli , M.C., Thies J., Masiello C.A., Hockaday W.C. and Crowley D. 2011. Biochar effects on soil biota - A review. Soil Biol Biochem, (43), 1812-1836.

12. Major J., Rondon M., Molina D., Riha S.J. and Lehmann J. 2012. Nutrient leaching in a Colombian Savanna oxisol amended with biochar. Journal of Environmental Quality (41), 1076.

13. Marra L.M., de Oliveira S. M., Sousa Soares C. L. F. and Moreira1 F. M. S. 2012. Solubilisation of inorganic phosphates by inoculant strains fromtropical legumes. Sci. Agric. (Piracicaba, Braz.), 68 (5), 603-609.

14. Masulili A., Utomo W. H. and Syechfani M. S. 2010. Rice husk biochar for rice based cropping system in acid soil the characteristics of rice husk biochar and its influence on the properties of acid sulfate soils and rice growth in West Kalimantan, Indonesia. Journal of Agricultural Science, 2(1), 39-47.
15. Nurita and Saleh M. 2016. Testing of Biofertilizer Formulation on Rice Crop at Tidal Lowland Area. Proceeding of National Seminar of Wet Land. Part 3, 916-920.

16. Rees F., Simonnot O.M., and More J.L. 2014. Short-term effects of biochar on soil heavy metal mobility are controlled by intra-particle diffusion and soil $\mathrm{pH}$ increase. European Journal of Soil Science, (65), 149-161.

17. Rousk J., Brookes P.C. and Bååth E. 2009. Contrasting soil $\mathrm{pH}$ effects on fungal and bacterial growth suggest functional redundancy in carbon mineralization. Applied and Environmental Microbiology (75), 1589-1596.

18. Santi L.P. and Goenadi D.H. 2010. Biochar utilization as microbe carrier for Utilsol soil aggregate stabilizer at Bogo Park-Lampung. Menara Perkebunan, 78(2), 52-60.

19. Saranya K., Santhana P., Kumutha K. and French J. 2011. Potential for biochar as an alternate carrier to lignite for the preparation of biofertilizers in India. Int. J. Agric. Biol, (4), 167-172.

20. Sohi S. P., Krull E., Lopez-Capel E. and Bol R., 2010. A review of biochar and its use and function in soil. In Donald L S (ed.) Advances in Agronomy. Vol. 105. Academic Press, New York. pp. 47-82.

21. Thies J.E. and Rillig M.C. 2009. Characteristics of biochar: biological properties. In Lehmann J, Joseph S (eds.) Biochar for Environmental Management: Science and Technology. Earthscan, London. pp. 85-105.

22. Vanek S.J., Thies J., Wang B., Hanley K. and Lehmann J. 2016. Pore-Size and Water Activity Effects on Survival of Rhizobium tropici in Biochar Inoculant Carriers. Jurnal Microb Biochem Technol, (8), 296-306. doi: 10.4172/1948-5948.1000300

23. Verheijen F., Jeffery S., Bastos A.C., Van der Velde M. and Diafas I. 2009. Biochar Application to Soils-A Critical Scientific Review of Effects on Soil Properties, Processes and Functions. Joint Research Centre (JRC) Scientific and Technical Report No.EUR 24099 EN. Office for the Official Publications of the European Communities, Luxembourg.

24. Xu G., Sun H.B., Shao J.B.,., and Chang S.X. 2014. Biochar had effects on phosphorus sorption and desorption in three soils with differing acidity. Ecology Engineering. J, (62), 54-60. 